\title{
Obituary
}

\section{In Memoriam: Professor Gregory Ashworth}

Place Branding and Public Diplomacy (2016) 12, 247-248. doi:10.1057/s41254-016-0050-6; published online 6 December 2016

The place branding community lost one of its most prominent figures with Greg Ashworth's passing in November 2016. Greg was one of the first to write about place marketing (in 1988, he published with Henk Voogd their first article on the topic and in 1990, their seminal book 'Selling the City'). He contributed to the field of place branding in several capacities: as author, as commentator, as keynote speaker, as conference organiser and, not least, as a reviewer and Editorial Board member of Place Branding and Public Diplomacy.

"Well, I never made any friends from reviewing papers", he had told me once... $\mathrm{He}$ was a strict but generous reviewer. Strict with everything, he thought, was the responsibility of an author: to be clear, to be concise and to be critical. He was generous with his praise and with his advice and guidance. That's what all great scholars are (or should be) like.

Greg Ashworth was born in Glasgow but he was not a Scot. He had lived for many years in Portsmouth, England but-in my eyes at least-he was not an Englishman. He spent more than half his life in Groningen, in the Netherlands, but he was not Dutch. Greg was his unique self... Cosmopolitan, certainly (he had travelled around the world and had family in several countries and continents), but he was locally rooted at the same time (he felt great affection for his adopted home town of Groningen). One thing that characterised him was his endless curiosity and capacity to be amazed- another mark of great scholars. Another thing was his typically English humour. I think a lot of people will agree that this was a great contribution of his to the social life of the place branding community.

Greg had an amazing track of publications on urban tourism, on place marketing and place branding. However, his main work was on heritage studies and heritage management and that is where he made his most significant impact. For his contribution to scholarship and knowledge, he was awarded in 2009 an Honorary Doctorate from Brighton University and in 2010 a Knighthood by the Queen of the Netherlands.

The last time I met Greg was in April 2016. He was his usual highly spirited and witty self and he delivered, as usual, a sensational public performance. But, it was apparent that his health issues were taking their toll. We discussed briefly, as we always did, our work on place branding. We had just finished what was destined to be the last piece we would write together and it included a reflection on the future of the field. Greg, weary from his deteriorating health, was not optimistic. "Does it work?", "Can we make it work?" he asked. "Why is nobody listening?” he added. I don't know the answers to his questions but I do know that we are all (that is, all readers of this journal) liable to answer them. Hopefully, in the affirmative.

I also know that Greg has left behind a rich, substantial legacy that we can use and build on. What precisely that means will 
become clearer with time and, surely, on the pages of this journal. For now, we say goodbye to a father-figure. Greg Ashworth's name will be removed from the Editorial Board of the journal but will surely remain in our thoughts, in our work and on our lips when we meet...
Mihalis Kavaratzis

School of Business, University of Leicester, Leicester, UK E-mail: m.kavaratzis@leicester.ac.uk 